\title{
THREE DIMENSIONAL PRINTING IN THE SOUTH AFRICAN INDUSTRIAL ENVIRONMENT
}

\author{
D. Dimitrov ${ }^{1}$, K. Schreve ${ }^{2}$, N. de Beer $^{3}$ and P. Christiane ${ }^{4}$ \\ Department of Industrial Engineering \\ University of Stellenbosch, South Africa \\ 1dimitrov@sun.ac.za, ${ }^{3}$ ndebeer@sun.ac.za \\ Department of Mechanical Engineering \\ University of Stellenbosch, South Africa \\ ${ }^{2}$ kschreve@sun.ac.za, ${ }^{4}$ peterjohn@sun.ac.za
}

\begin{abstract}
The current development of the rapid prototyping industry in South Africa is characterised by the strong dominance and fast growth in sales of three dimensional printers. Although it reflects the international trend, it seems that the industrial community lacks a clear appreciation of the real strength of this technology, especially with respect to the large variety of devices available today on the market. This paper surveys the current state and capabilities of three dimensional printing (3DP). Based on its technical background - the ink-jet printing known from the printer and plotter industry - a classification structure is developed and proposed. Different printing techniques and process concepts, together with their advantages and limitations, are described and analysed. Typical examples from three completely different application areas - manufacturing, medicine, and architecture - are presented and discussed. Some basic considerations for an informed selection of the right technology for a particular application are then presented.
\end{abstract}

\section{OPSOMMING}

Sterk groei in die verkope van drie dimensionele drukkers (3DP) kenmerk die onlangse groei in die snelle prototipe industrie in Suid-Afrika. Ten spyte daarvan dat hierdie ' $n$ internasionale tendens reflekteer, blyk dit dat die werklike waarde van die tegnologie nog nie ten volle waardeer word in die industriële gemeenskap nie, veral aangesien daar so ' $\mathrm{n}$ groot verskeidenheid masj iene in die mark beskikbaar is. ' $n$ Oorsig oor die huidige stand en vermoë van drie dimensionele drukkers word hier gegee. 'n Klassifikasiestruktuur - gebaseer op die inkspuitdrukkertegnologie - word ontwikkel en voorgestel. Verskillende druktegnieke en konsepprosesse word ontleed. Daar word ook gekyk na die voor- en nadele hiervan. Tipiese voorbeelde van drie verskillende toepassings (vervaardiging, medies, en argitektuur) word aangebied en bespreek. Basiese riglyne vir ' $n$ ingeligte keuse van die regte tegnologie vir ' $n$ spesifieke toepassing word ook gegee. 


\section{INTRODUCTION}

Layer manufacturing (LM) technologies have expanded vastly over the 15 years of its history. Originally seen as mostly suitable for rapid prototyping (RP), these processes are no longer used exclusively for that purpose. With the advent of new materials along with new processes, each technology has been applied in diverse fields. However, for improvement it is critical to understand exactly what the capability of each individual technology is in order to compare current processes and techniques, or even future improvements.

During the last decade, intensive research efforts have been focused primarily on the high-end additive processes (i.e. systems costing more than US $\$ 100000$, systems not suitable for office use, and systems with a fairly large footprint [1]), and above all on the stereolithography (SLA) and the selective laser sintering (SLS) technologies, exploring various issues mostly related to process control and material property improvement. In recent years three dimensional printing (3DP) has come to the fore as a very competitive process in terms of cost and speed. Sales of related equipment have increased significantly compared to other RP machines (Figure 1). These devices were developed, and are still seen, mostly as 'concept modellers'. However, with a larger selection of materials available today, as well as a wide variety of post-treatment procedures, the scope for this technology is growing quickly - far beyond the original idea of generating design iterations or inexpensive metal parts directly from a CAD-file.

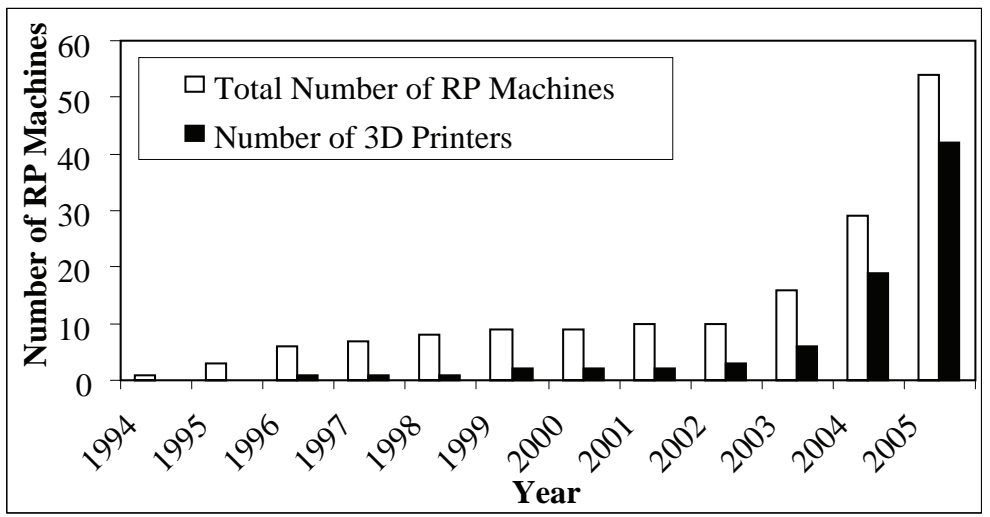

Figure 1: Growth of RP equipment sales (Source: Wohlers Associates, Inc. [2])

A similar trend is seen in South Africa (Figure 2a), with a wide spread of OEMs being represented (Figure $2 \mathrm{~b}$ ). While these machines were mostly available at academic and research institutions, the last few years have seen a rapid spread into industry, with 3D printers capturing the bulk of the market. It is therefore timely to present a paper classifying the technologies and comparing the capabilities of available 3D printing machines. 
Generally speaking, three dimensional printing is a development of ink-jet printing technology, which was originally developed some 30 years ago. There are two types of ink-jet printing [4]:

- $\quad$ Continuous ink-jet printing (continuous deposition) uses a stream of charged droplets and deflects those, which are to be used for printing.

- $\quad$ Drop-on-demand ink-jet printing positions the ink-jet printing head over the place where printing is to occur before depositing a droplet.

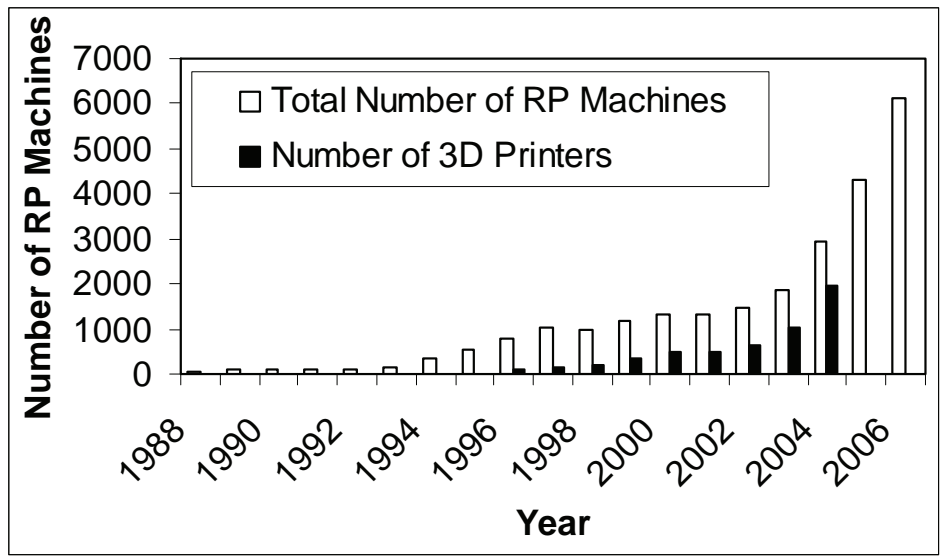

(a)

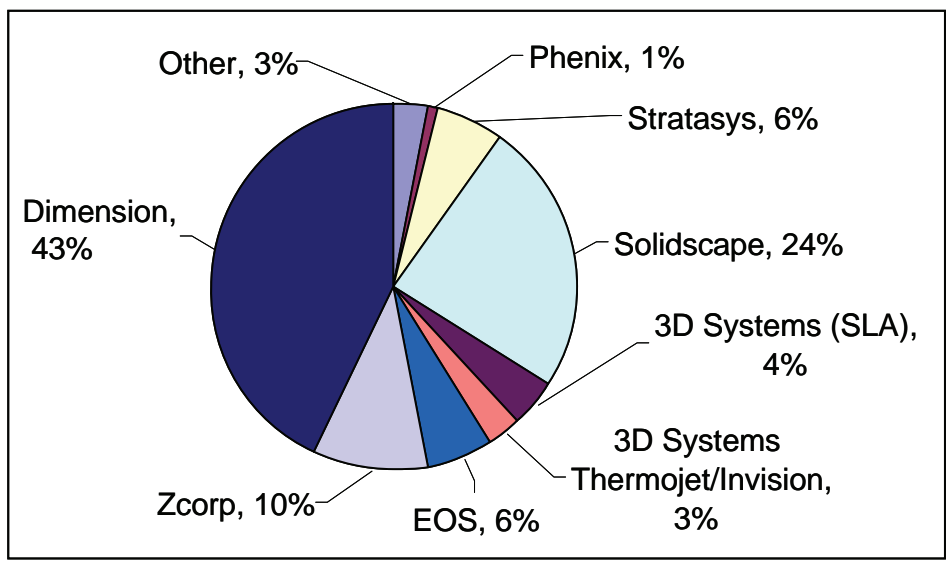

(b)

Figure 2: Rapid prototyping machine sales in South Africa [3] 
The capacity for subsequent overprinting leads to the building of the third dimension, whereby each layer must solidify. This allows a multi-layer and multimaterial construction, hence the name 'three dimensional printing'.

During the last 15 years a large variety of 3D printing techniques were introduced into the rapid prototyping (RP) industry. All these techniques have their roots in inkjet printing technology. The use of a printer head is the only element that they have in common. The printer head - in whatever version it might be applied - serves to shoot either droplets of binder or liquid-to-solid compound, and so forms a layer of an RP model. The shooting of droplets of the actual building material (liquid-to-solid compound) in drop-on-demand mode is known as drop-on-drop (DoD) deposition, while the shooting of droplets of binder on the powder material is called drop-onpowder (DoP), or drop-on-bed (DoB) deposition.

This paper proposes a classification of 3D printing technologies. With the wide variety of processes available and the inconsistent use of the term ' $3 \mathrm{D}$ printing' on the Internet (even SLA is sometimes referred to as 3D printing) it will be useful to establish a technically sound classification. Understanding the underlying technologies and having a clear distinction between different methods is also useful when deciding what kind of equipment to acquire for a particular application. The authors also make a brief analysis of the capabilities of the different technologies, and give references where further details can be found. Finally, some typical applications are given. They show some innovative South African approaches.

\section{DEFINITION AND CLASSIFICATION}

\subsection{Three dimensional printing - background and definition}

The birth of solid freeform manufacturing (SFM) can be traced back to 1988 when the first stereolithography machine was introduced. The development of the idea for rapid prototyping started, however, a few years earlier. In the meantime many new proposals emerged and numerous patents on the subject were submitted. Some of the early processes disappeared completely; some others are still in use, but without further development. Table 1 below gives an overview.

It can be seen from Table 1 that 3D printing - in its drop-on-bed version - was one of the first developments, and its ongoing improvement is far from exhausted. Although a patent was filed at the end of 1989, it was granted only four years later. Commercial use had to wait for another four years, by which time other processes such as stereolithography (SLA), fused deposition modelling (FDM), or laminated object manufacturing (LOM) were widely established and drew large crowds at international fairs.

The main characteristics of the two principal forms of ink-jet printing can be summarised as follows:

- $\quad$ Drop formation velocity:

- Continuous printing: very rapid droplet generation $(60 \mathrm{kHz})$.

- Drop-on-demand: substantially lower (5-6 kHz). 
- $\quad$ Fluid viscosity - the continuous drop formation requires very low viscosity fluids; relatively low values by drop-on-demand.

- $\quad$ The fluid must be able to conduct electricity (even if only weakly), while the excitation by drop-on-demand is assured by the pressuring device.

\begin{tabular}{|l|l|l|}
\hline Name & Acronym & Development Years \\
\hline Stereolithography & SLA & 1986-1988 \\
\hline Solid ground curing & SGC & 1986-1988 (disappeared in 1999) \\
\hline Laminated object manufacturing & LOM & $1985-1991$ \\
\hline Fused deposition modelling & FDM & $1988-1991$ \\
\hline Selective laser sintering & SLS & $1987-1992$ \\
\hline 3D printing (Drop-on-bed) & 3DP & $1985-1997$ \\
\hline
\end{tabular}

Table 1: LM technologies, acronyms and development years [5]

Obviously there must be some target properties of the fluids that make them 'printable'. These properties must allow the technology to [4]

- $\quad$ maximise the solid loading of suspensions

- $\quad$ keep fluid properties within a printable window

- $\quad$ stabilise suspension against settling

These target properties are given by the principles of fluid mechanics. The key parameters are the Reynolds number (Re) and the Weber number (We). Suitable fluids for drop-on-demand printing, for example, normally satisfy the condition

$$
1<\operatorname{Re} / \sqrt{W e}<10 \text {. }
$$

\subsection{Classification of the 3D printing techniques}

During the last 15 years a large variety of 3D printing techniques were introduced into the rapid prototyping (RP) industry. As mentioned above all, these techniques have their roots in ink-jet printing. Depending on the ink-jet method, a thermal, polymer, or physical phase change takes place. Table 2 shows how different deposition techniques link up to the different technologies that make use of them.

\subsubsection{Drop-on-drop deposition}

Thermal phase change ink-jets 
The process, introduced originally by Sanders Prototype, Inc. (now undertaken by Solidscape, Inc.), makes use of two print heads with single jets: one deposits the thermoplastic building material while the other deposits supporting wax. The supporting wax material is deposited at the same time as the thermoplastic. The liquefied build material cools and solidifies upon contact with the previous layer as it is ejected from the print head. After each layer is completed, a cutter removes approximately $0.025 \mathrm{~mm}$ from the top surface to provide a smooth, even surface for the next layer [7]. The build platform is adjusted to receive the next layer, and the process is repeated for the next cross-section of build and support material (Figure 3). Smooth, cosmetic surface quality can be achieved by pre-tracing the perimeter of a layer prior to filling in the interior. Exceptional accuracy further characterises this method. The process can be considered as a hybrid of FDM and 3D printing. Solidscape Inc. calls it '3D plotting'. Their individual technical characteristics are displayed in Table 3.

\begin{tabular}{|ll}
\hline Aimed deposition process & Technology \\
\hline Drop-on-drop deposition & 3D plotting \\
& Multi-jet modelling \\
\hline Drop-on-powder deposition & 3D printing \\
\hline Continuous deposition & Fused deposition modelling \\
\hline
\end{tabular}

Table 2: Summary of processes and corresponding technologies [6]

Another example of the thermal phase change concept is Multi-J et Modelling ${ }^{\text {TM }}$ as introduced by 3D Systems. It uses several hundred nozzles in a wide head configuration to deposit molten plastic for layering [8]. The system is fast, compared to most other RP techniques, and produces good appearance models with minimal operator effort. The system is illustrated in Figure 4.

The product that incorporates this ink-jet printing technology is the Thermol et Modeler. All thermal phase change ink-jets have material limitations and make fragile parts. The applications range from concept models to precise casting patterns for industry and the arts, particularly jewellery.

\section{Photopolymer phase change ink-jets}

The concept is based on the use of photopolymers as building materials. A wide area ink-jet head layerwise deposits both build and support material. It subsequently completely cures each layer after it is deposited with a UV flood lamp mounted on the print head. The support material, which is also a photopolymer, is removed by washing it away in a secondary operation.

The process, called Polyj et ${ }^{T M}$ was introduced some six years ago by Objet Geometries Ltd., an Israeli company, first on their Quadra machine. Meantime this company expanded its product range by introducing the EDEN models. A similar photopolymer-based system called InVision ${ }^{\text {TM }}$ was introduced by 3D Systems in 2003. The typical application of the photopolymer phase change ink-jets is conceptual 
modelling, characterised by high quality models.

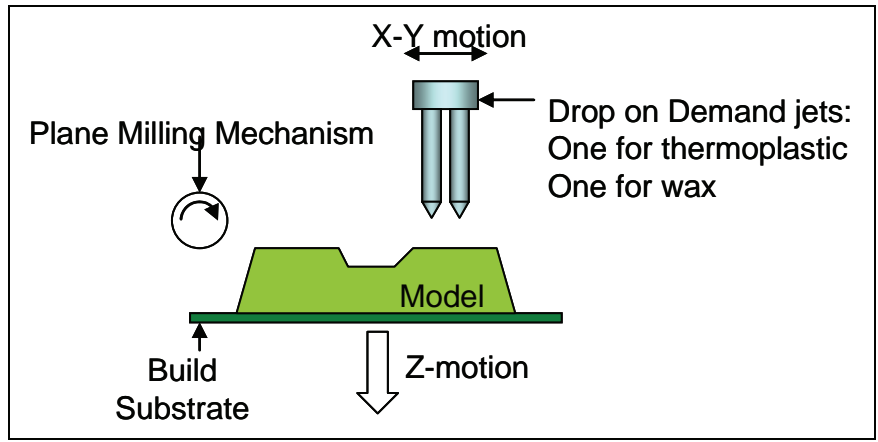

Figure 3: Schematic diagram of 3D plotting

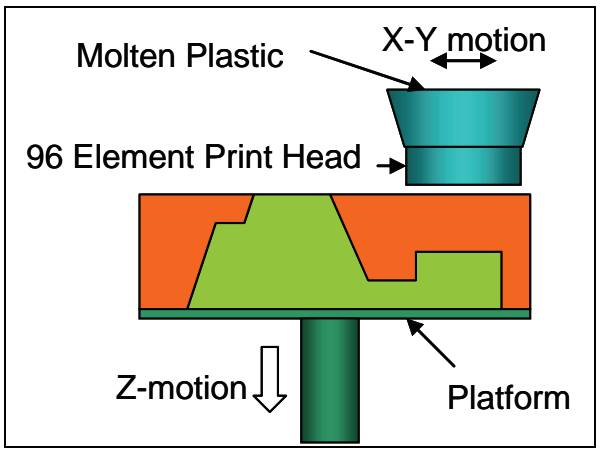

Figure 4: Schematic diagram of Multi-J et Modelling ${ }^{\text {TM }}$

\subsubsection{Drop-on-powder deposition}

US Patent 5,204,055 defines 3D printing as:

a process for making a component by depositing a first layer of a fluent porous material, such as a powder, in a confined region and then depositing a binder material to selected regions of the layer of powder material to produce a layer of bonded powder material at the selected regions. Such steps are repeated a selected number of times to produce successive layers of selected regions of bonded powder material so as to form the desired component. The unbounded material is then removed. [9]

This solution was developed and patented by the Massachusetts Institute of Technology, and then licensed to different companies depending on the 
applications. Its work principle is illustrated in Figure 5.

Soligen, Inc. had first commercialised it for building ceramic shells for direct investment casting. Later Z-Corporation utilised it in a variety of printers.

Another application of the drop-on-powder concept was introduced by the ProMetal ${ }^{\mathrm{TM}}$ division of Extrude Hone Corporation. It provides the user with the ability to go directly from CAD data to steel moulding inserts. It uses an electrostatic inkjet printing head to deposit a liquid binder on to the powder metals. The part is built one layer at a time, based on the sliced cross-sectional data. The metal powder layer is spread on the build piston, and a sliced layer is printed onto the powder layer as the ink-jet print head deposits droplets of binder that are in turn dried by the binder drying lamp [7]. The process is repeated until the part build is completed.

ProMetal provides two printers that make use of this 3DP technology to produce metal parts. Their individual technical characteristics can be viewed in Table 3.

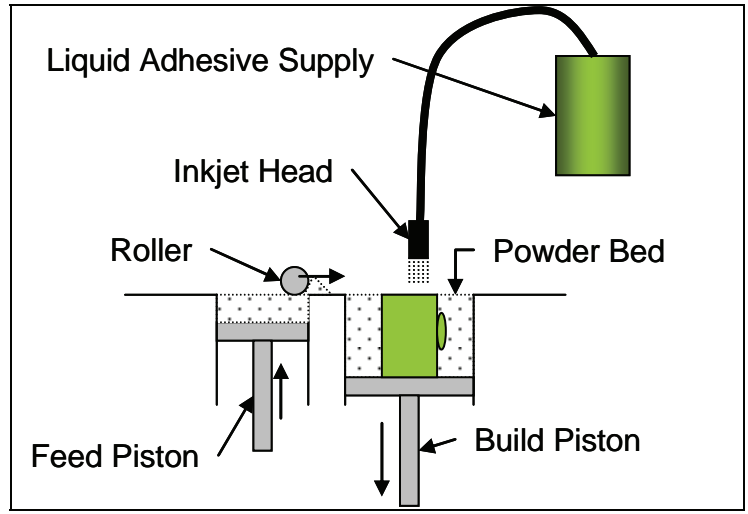

Figure 5: Schematic diagram of 3D printing - drop-on-bed

\subsubsection{Continuous deposition}

The fused deposition modelling (FDM) process, in combination with the continuous ink-jet printing technique, is utilised by Stratasys in two of its low cost products, Prodigy Plus and Dimension.

FDM machines have an extruder head through which material is extruded in a semiliquid state to form the part (see Figure 6). The raw material is on a spool as a thin wire (diameter $1.27 \mathrm{~mm}$ ). This is fed into the extruder head and heated. Two materials are deposited simultaneously: the principal material is used to form the part, while a secondary material is deposited to form a support structure for overhanging parts of the component. The secondary material is cheaper than the primary material, and can be broken or washed away after building. 


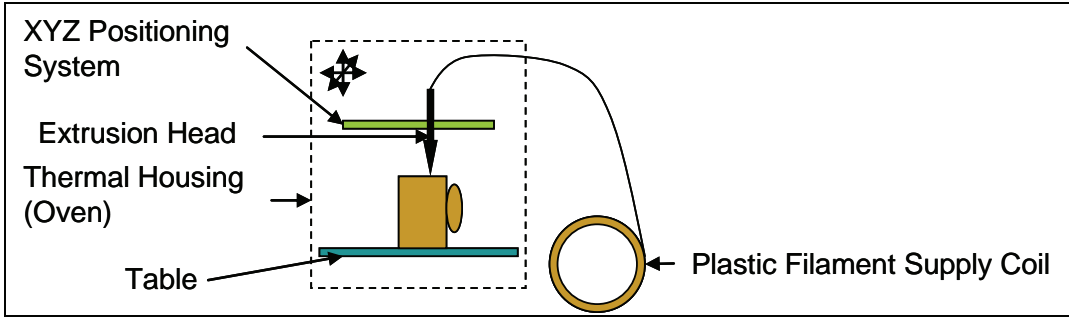

Figure 6: Fused Deposition Modelling

A wide range of materials can be used. ABS plastics in different colours are used frequently, but wax and elastomers are also used. The material of the final product is not hygroscopic and the parts are geometrically stable. The materials are cheap compared to many other RP materials, and they are clean and safe to use in an office environment.

Prodigy Plus makes use of ABS plastic as modelling material. It is equipped with the design tool called WaterWorks, which allows a designer to create mechanisms whose moving parts are built assembled. The Dimension and Prodigy Plus printers have similar specifications, with one of the most apparent differences being the support material used. While the Dimension printer makes use of the Break Away Support System $\left(\right.$ BASS $\left.^{\mathrm{TM}}\right)$, Prodigy Plus incorporates the WaterWorks automated support system [7].

\subsubsection{Classification}

Based on the variety of applications utilising the 3D printing process, the following classification of 3D printing techniques can be derived (Figure 7).

Figure 7

From the diagram above the similarities of the drop-on-drop and the continuous printing techniques can be seen, where the 'printable fluid' and the building substance are one and the same material. This means that the building material has to meet two requirements related, first, to the fluid's printability as discussed above, and second, to the purpose of building the model - i.e. the intended application. The need to fulfil these requirements puts substantial limits on the range of materials suitable for a particular application. In contrast, the drop-on-bed (powder) version distributes the responsibility to meet the requirements to two different substances. In fact, almost every material can be brought to a powder state - the starting point also of the SLS process. In this way the task to make it possible for this material to process in a 3DP device is moved to the task to find a suitable binding liquid. This scenario predetermines a much larger variety of suitable combinations, and thus a much larger application range. The possibility to use infiltrating agents in the next stage of the model manufacturing process further extends the variety of applications [10]. 


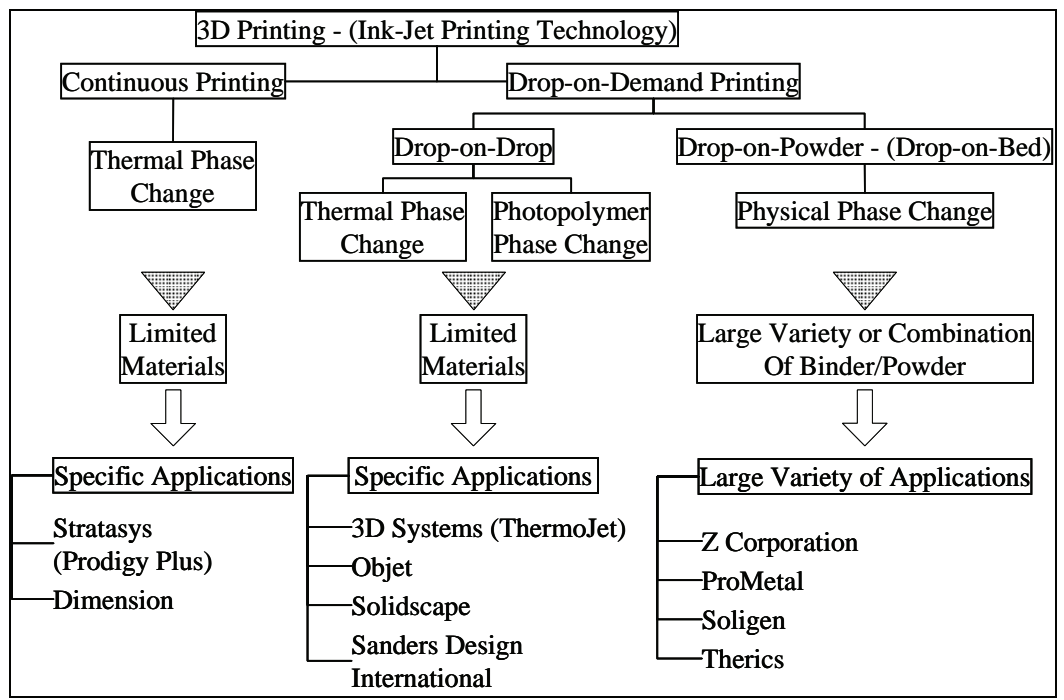

Figure 7: Classification structure of the 3D printing techniques as utilised in layer manufacturing applications

\section{TECHNICAL AND ECONOMIC CHARACTERISTICS}

With the above classification, a framework is now established from which current and future technologies can be compared with regards to their individual technical and economic characteristics. Depending on the application, one technology will be more suitable than another to accomplish the task. As far as possible, this study has sought to identify the dominant commercially available 3D printing technologies that fall within the classification framework discussed above. The characteristics of each of the printing machines (printers) have been tabulated in Table 3 below, which compares typical attributes such as geometry and size, materials, accuracy and model quality, build speed and price, according to each core technology.

Some observations can be summarized as follows:

- $\quad$ The hybrid FDM technology from Stratasys is currently the only 3D printing process that uses a continuous material deposition technique.

- Machine sizes and build envelopes vary widely in accordance with the machine's intended application. ProMetal's metal and sand 3DP machines currently have the largest build volumes, while smaller build volumes can be found in 3D System's InVision ${ }^{\mathrm{TM}}$ 3D Printer, and Solidscape's T66 and T612 models.

- $\quad$ Apart from the powder-based (drop-on-bed) printing processes, all other 
techniques require some kind of extra support material that needs to be removed from the main build material. On the other hand, the drop-on-bed technologies are the only ones that make use of a powder binding material and require post-infiltration to increase model quality. This can be seen as either a drawback or a benefit. It is a drawback since post-processing time increases overall lead time. It is advantageous since a suitable infiltration material can alter the model's physical properties and thereby increase its range of applications.

- $\quad$ Accuracy capabilities of each technology are not generally reported in great detail. An apparent tendency is that accuracy capabilities are in many cases reported only as some single ' \pm ' value. But research has indicated that achievable accuracy is strongly related, among other things, to the relevant build axes of the machine. The reported values do however give some measure by which a comparison can be made. It seems that Solidscape and Sanders Design International's 3D plotting machines are currently showing the best accuracy results, along with having the thinnest layer thicknesses (13 and 12 microns respectively).

- $\quad$ Other characteristics that are also poorly specified or reported are surface roughness of models and the build speeds of each technology. Consequently, in cases where information is given, it is not done according to a samestandard format. Surface roughness, for example, is reported as an RMS value for Solidscape's machines, while $R_{a}$ values have been calculated in other cases.

- $\quad$ Objet's Polyj et technology currently provides material with the largest tensile strength (42.3 MPa), while Stratasys and Dimension's ABS parts show good tensile strength at a reported $35 \mathrm{MPa}$.

- $\quad$ The prices of 3D printing machines range between $\$ 25,900$ and $\$ 1.2$ million for the ZPrinter 310 and ProMetal S15 machines respectively. The increasing market share of Stratasys (Dimension) and Z Corporation's Z 310 can be directly attributed to their being the lowest-cost systems available at the moment.

- The costs in the table are based on prices quoted in 2005, and should only be used as a comparative guide.

- Unless otherwise stated, the information in the table is from the machine suppliers' websites (in April 2007).

\section{APPLICATIONS}

Three application examples are described below, clearly showing the large versatility of this technology. It impressively demonstrates how, within only one decade, the technology has evolved drastically from being mainly a tool for conceptual modelling and design iterations, all the way to a product development acceleration and communication approach. The first example shows how functional metal prototypes can be produced using a 3D printed pattern to manufacture 
foundry tooling for sand casting. In the next example a medical model is presented and discussed. An architectural model for marketing purposes concludes this short review.

\subsection{Rapid tooling}

Often a small number of components is needed to test a product before it goes into serial production. Rapid tooling is a good way of making functional prototypes in final geometry and material for the pre-production phase, avoiding large expenses for production tooling. This example illustrates the ability of the 3D printers to deliver low-cost solutions in areas originally reserved for high-end RP systems. Usually 3D printing models combine very well with secondary processes, such as investment, vacuum, or sand casting. In these cases the 3D printed parts are used mainly as patterns for the secondary process. Depending on the process, such patterns are used directly to produce the component or indirectly to create a mould, allowing small production runs of typically 10 to 30, and even several hundred components.

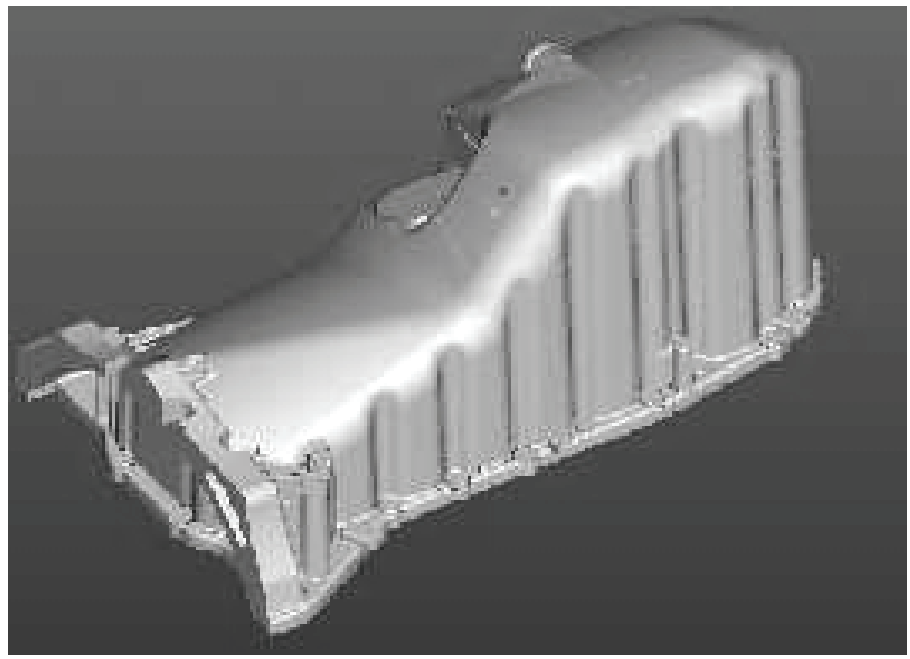

Figure 8: Engine sump

The production part of the sump shown in Figure 8 will be a die casting. The prototypes were sand cast using 3D printed patterns to produce the foundry tooling. One of the major challenges in creating the sump and other prototypes was the limited time available and the complexity of their geometries. Of significance to the oil sump in particular was its deep draws and very thin anti-surge baffles that needed to be accommodated in the moulding process. Its size $(500 \times 330 \times 270 \mathrm{~mm})$ also meant that this pattern would have to be assembled from more than one build. A total of 80 sumps was ordered for various tests, enabling the incorporation even of production planning in the product development phase. 


\begin{tabular}{|c|c|c|c|c|c|c|c|c|c|}
\hline \multicolumn{2}{|c|}{ 3D Printers } & \multirow[b]{2}{*}{$\begin{array}{c}\text { Core Tech- } \\
\text { nology }\end{array}$} & \multicolumn{2}{|c|}{ Geometry and Size } & \multicolumn{5}{|c|}{ Materials } \\
\hline 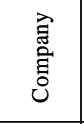 & Machine & & $\begin{array}{l}\text { Machine } \\
\text { Size }[\mathrm{cm}]\end{array}$ & $\begin{array}{c}\text { Build } \\
\text { Envelope } \\
{[\mathrm{cm}](\mathrm{X},} \\
\mathrm{Y}, \mathrm{Z})\end{array}$ & 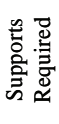 & Building Material & $\begin{array}{l}\text { Support } \\
\text { Material }\end{array}$ & Binder & $\begin{array}{c}\text { Infiltra- } \\
\text { tion } \\
\text { Agent }\end{array}$ \\
\hline \multirow{3}{*}{ 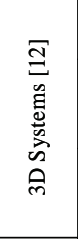 } & ThermoJet & \multirow{3}{*}{ MJM (DoD) } & $\begin{array}{c}137 \times 76 \times x \\
112\end{array}$ & $\begin{array}{c}25 \times 19 \times \\
20\end{array}$ & Yes & $\begin{array}{c}\text { ThermoJet } 88 \& \\
2000\end{array}$ & $\begin{array}{l}\text { VisiJet }{ }^{\circledR} \\
\text { (Wax) }\end{array}$ & N/A & N/A \\
\hline & $\begin{array}{l}\text { InVision }^{\mathrm{TM}} \\
\text { 3D Printer }\end{array}$ & & $\begin{array}{c}77 \times 124 \times \\
148\end{array}$ & $\begin{array}{c}29.8 \mathrm{x} \\
18.5 \mathrm{x} \\
20.3 \\
\end{array}$ & Yes & $\begin{array}{c}\text { Accura® VisiJet } \\
\text { M100 }\end{array}$ & $\begin{array}{c}\text { VisiJet@ } \\
\text { S100 }\end{array}$ & N/A & N/A \\
\hline & $\begin{array}{l}\text { InVision }^{\mathrm{TM}} \\
\text { HR 3D } \\
\text { Printer } \\
\end{array}$ & & $\begin{array}{c}77 \times 124 \times \\
148\end{array}$ & $\begin{array}{c}12.7 \times \\
17.8 \times 5\end{array}$ & Yes & VisiJet HR-M100 & $\begin{array}{c}\text { VisiJet@ } \\
\text { S100 }\end{array}$ & N/A & N/A \\
\hline 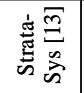 & Prodigy Plus & \multirow{2}{*}{ 畜总 } & $\begin{array}{c}69 \times 86 \times \\
104\end{array}$ & \multirow{2}{*}{$\begin{array}{c}20.3 x \\
20.3 x \\
30.5\end{array}$} & Yes & ABS Plastic & $\begin{array}{l}\text { Soluble } \\
\text { Support } \\
\text { Material }\end{array}$ & N/A & N/A \\
\hline $\begin{array}{c}\text { Dimen- } \\
\text { sion } \\
{[14]}\end{array}$ & $\begin{array}{l}\text { Dimen-sion } \\
\text { SST }\end{array}$ & & $\begin{array}{c}69 \times 91 \times \\
104\end{array}$ & & Yes & ABS Plastic & $\begin{array}{l}\text { BASSTM } \\
\text { Support } \\
\text { Material }\end{array}$ & N/A & N/A \\
\hline \multirow{3}{*}{ 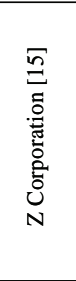 } & Z406 & \multirow{3}{*}{$\begin{array}{c}\text { 3DP } \\
(\mathrm{DoB})\end{array}$} & $\begin{array}{c}102 \times 79 \times \\
112\end{array}$ & $\begin{array}{c}20.3 \mathrm{x} \\
25.4 \mathrm{x} \\
20.3 \\
\end{array}$ & (No) & \multirow{3}{*}{$\begin{array}{c}\text { zp102; zp15e; } \\
\text { zp250; } \\
\text { ZCast }^{\mathrm{TM}} 501\end{array}$} & \multirow{3}{*}{$\begin{array}{c}\text { Same as } \\
\text { build } \\
\text { material }\end{array}$} & \multirow{3}{*}{$\begin{array}{c}\text { zb51; } \\
\text { zb56 }\end{array}$} & \multirow{3}{*}{ 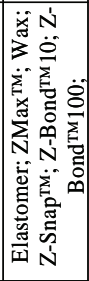 } \\
\hline & $\mathrm{Z} 810$ & & $\begin{array}{c}241 \times 114 \\
\times 193\end{array}$ & $\begin{array}{c}50 \times 60 \times \\
40\end{array}$ & (No) & & & & \\
\hline & ZPrinter 310 & & $\begin{array}{c}74 \times 81 \times \\
109\end{array}$ & $\begin{array}{c}20.3 \mathrm{x} \\
25.4 \mathrm{x} \\
20.3 \\
\end{array}$ & (No) & & & & \\
\hline \multirow{2}{*}{$\begin{array}{l}\underset{\sigma}{己} \\
\frac{0}{0} \\
\frac{0}{0}\end{array}$} & Eden $^{\mathrm{TM}} 260$ & \multirow{2}{*}{$\begin{array}{l}\text { PolyJet } \\
\text { (DoD) }\end{array}$} & $\begin{array}{c}87 \times 74 \times \\
120\end{array}$ & $\begin{array}{c}25.6 \times 25 \\
\times 20.3\end{array}$ & Yes & \multirow{2}{*}{$\begin{array}{l}\text { FullCure M720 } \\
\text { (Photo-polymer) }\end{array}$} & \multirow{2}{*}{$\begin{array}{c}\text { FullCure } \\
\text { S705 } \\
\text { (Photo- } \\
\text { polymer) }\end{array}$} & \multirow[t]{2}{*}{ N/A } & \multirow[t]{2}{*}{ N/A } \\
\hline & Eden $^{\text {TM}} 330$ & & \begin{tabular}{|c|}
$132 \times 99 \times$ \\
120 \\
\end{tabular} & \begin{tabular}{|c|}
$33.6 \times$ \\
$32.6 \times 20$ \\
\end{tabular} & Yes & & & & \\
\hline \multirow{3}{*}{ 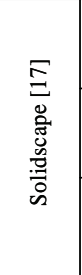 } & T612 & \multirow{3}{*}{$\begin{array}{l}\text { 3D Plotting } \\
\text { (DoD) }\end{array}$} & $\begin{array}{c}86.4 \times 66 \\
\times 128.3\end{array}$ & $\begin{array}{c}13.4 \mathrm{x} \\
15.2 \mathrm{x} \\
15.2 \\
\end{array}$ & Yes & \multirow{3}{*}{$\begin{array}{l}\text { ProtoBuild }^{\mathrm{TM}} \\
\text { Material } \\
\text { (Proprietary } \\
\text { thermoplastic) }\end{array}$} & \multirow{3}{*}{ 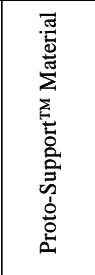 } & N/A & N/A \\
\hline & T66 & & $\begin{array}{c}53 \times 48 \times \\
53\end{array}$ & $\begin{array}{c}15.2 \mathrm{x} \\
15.2 \mathrm{x} \\
15.2 \\
\end{array}$ & Yes & & & N/A & N/A \\
\hline & $\begin{array}{l}\text { Pattern- } \\
\text { Maker }\end{array}$ & & $\begin{array}{c}52 \times 44.5 \\
\times 58.5\end{array}$ & $\begin{array}{c}30.5 \mathrm{x} \\
15.2 \mathrm{x} \\
21.6\end{array}$ & Yes & & & N/A & N/A \\
\hline $\begin{array}{c}\text { Sanders } \\
{[18]}\end{array}$ & $\begin{array}{l}\text { Rapid Tool } \\
\text { Maker }\end{array}$ & $\begin{array}{l}\text { 3D Plotting } \\
\text { (DoD) }\end{array}$ & $\begin{array}{c}174 \times 66 \times \\
167.5\end{array}$ & $\begin{array}{c}90 \times 30 \times \\
30\end{array}$ & Yes & $\begin{array}{l}\text { Proprietary } \\
\text { thermoplastic }\end{array}$ & Wax & N/A & N/A \\
\hline \multirow{2}{*}{$\begin{array}{c}\text { Extrude } \\
\text { Hone } \\
{[19]}\end{array}$} & R2 & $\begin{array}{c}\text { Metal 3DP } \\
(\mathrm{DoB})\end{array}$ & \begin{tabular}{|c|}
$180 \times 120$ \\
$\times 150$ \\
\end{tabular} & $\begin{array}{c}20 \times 20 \times \\
15 \\
\end{array}$ & No & $\begin{array}{c}\text { Stainless Steel, } \\
\text { other metals }\end{array}$ & \begin{tabular}{|c|}
$\begin{array}{c}\text { Same as } \\
\text { build }\end{array}$ \\
\end{tabular} & \begin{tabular}{|c|} 
S- \\
Binder
\end{tabular} & Bronze \\
\hline & S15 & $\begin{array}{l}\text { Sand 3DP } \\
\text { (DoB) }\end{array}$ & \begin{tabular}{|c|}
$330 \times 300$ \\
$\times 200$ \\
\end{tabular} & $\begin{array}{c}150 \times 75 \times \\
75\end{array}$ & No & Sand & & $\mathrm{N} / \mathrm{S}$ & N/A \\
\hline
\end{tabular}

Table 3a: Technical and cost characteristics of 3D printing 


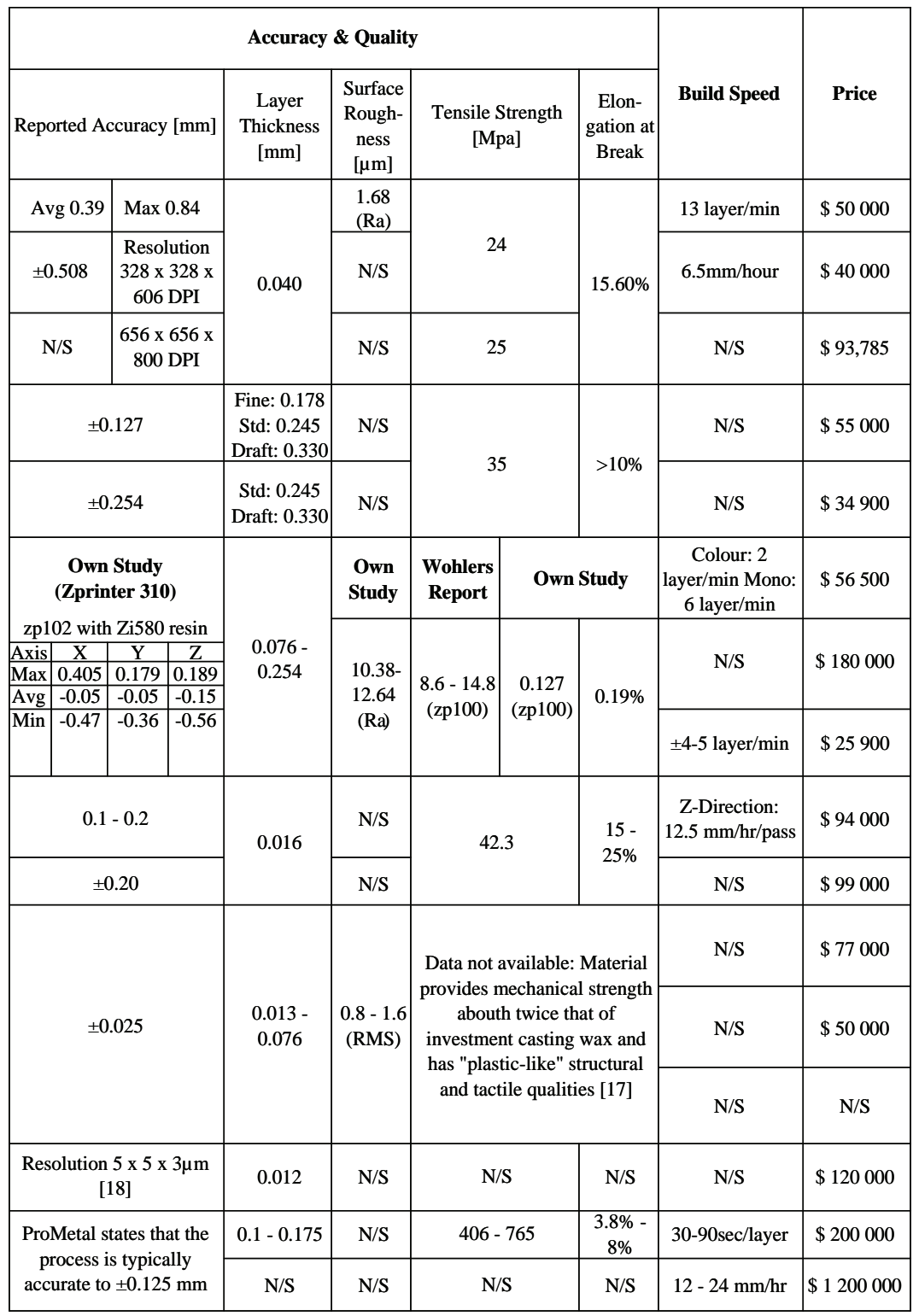

Table 3b: Technical and Cost Characteristics of 3D Printing 
The model was divided into five different sections to fit into the build volume of the printer. These sections were printed as four builds, taking approximately 8-9 hours per build. Finishing steps include resin-infiltration, curing, assembly, and surface quality preparation. Quality inspection is concurrently applied to ensure that dimensional and geometrical accuracy specifications are met. The full-scale printed sections were hand-finished and assembled using the critical dimensions to control quality. The general tolerances achieved fell well within casting capabilities of \pm 0.8 $\mathrm{mm}[20]$.

Layered manufacturing makes it possible to create products of very complex shapes. Undercuts and complex curved shapes can easily be produced. This is the property that makes this process attractive for medical modelling. In this example a model was made of the maxilla. The model (Figure 9a) is grown from an STL file generated from a CT scan.

The model is used as a surgical aid for dental implants. Ensuring that the hole for the implants is drilled to the correct depth and orientation is a complex operation. The 3D model is therefore ideal for the surgeon to plan the operation, and it saves time and unnecessary trauma for the patient. However, in this case the process was taken a step further. Using the RP model, a drill guide (Figure 9b) was manufactured. The guide was used during surgery to position and orientate the drill. The operation was a great success, with significant savings in theatre time. Also, by being able to place the drill accurately, the surgical risks are reduced and the patient may be able to recover faster.

The model (Figure 9a) was made using an Objet machine. It took 6 hours of printing and 13 minutes post-processing, mainly to remove the support structure with a waterjet. The layer thickness $(-0.016 \mathrm{~mm})$ of this machine means that the surface finish of the model is very good compared to other RP processes. The material is strong and handles very well, and poses no problems for the manufacture of the drill guide. One disadvantage is that the model is very opaque. Transparency helps the surgeon to see where the drill goes into the bone and therefore to ensure that the hole is far enough from the bone surface.

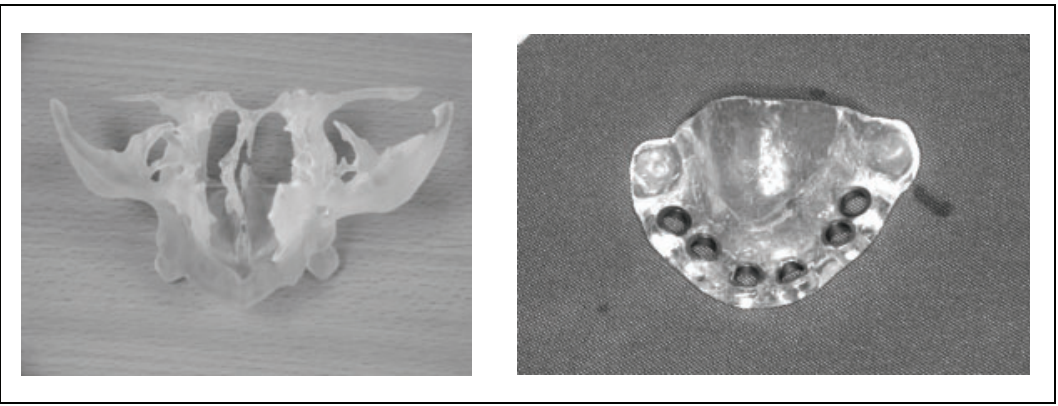

(a) Objet model of the maxilla

(b) Dental drill guide

Figure 9: Medical models using RP technology 


\subsection{Architectural modelling}

RP models can also be used for architectural visualisation. It is possible to make a model quickly for marketing or planning purposes. However, the build volume of the RP machines is often too small to make an architectural model of sufficient scale. This should not be a limitation, as CAD models can be cut into smaller sections. These sections can then be built separately and assembled afterwards. The Stellenbosch University's Laboratory for Rapid Product Development has developed assembly techniques for models from Z Corporation 3D printers, and regularly makes models larger than the work envelope of the printer.

Since an architectural model is scaled down significantly, many features become very small. The smallest features that can be grown on the 3D printer depend on the geometry. Wall thickness of box-like structures can go down to $1 \mathrm{~mm}$, depending on their size. Cylindrical pins must have a diameter of at least $2 \mathrm{~mm}$, depending on their length. Thus, scaling down a building's CAD model cannot be isotropic. Minor detail must be enlarged. Walls must be made thicker. Substantial work must be done on the CAD model before a scaled prototype can be grown.

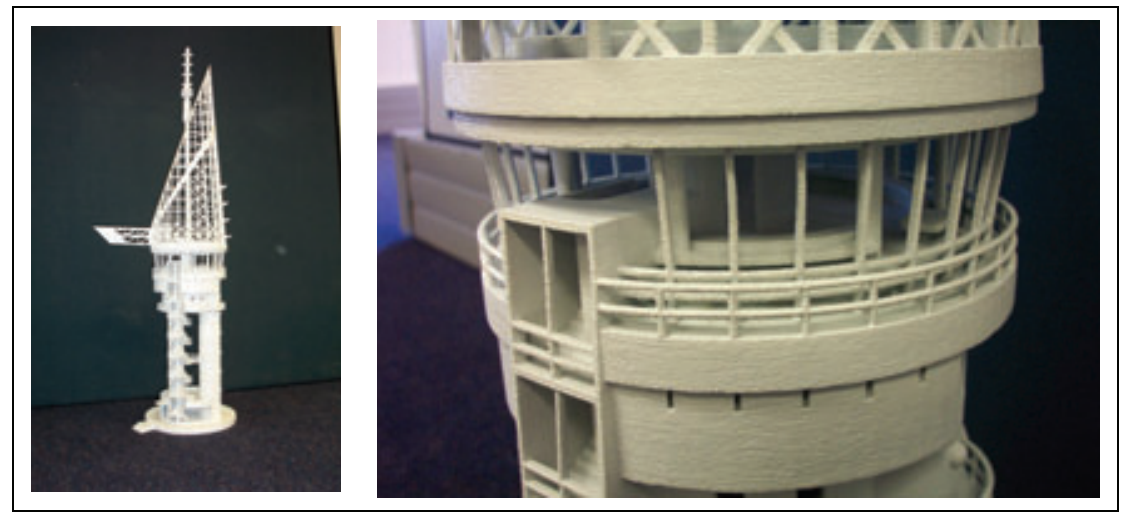

(a)

(b)

Figure 10: Model of the Millennium Tower built on a Z Corp 3D printer

Durban's Millennium Tower (Figure 10) is a good example of the intricate detail and complexity that can be achieved by using RP models for architectural visualisation. The model was built in 13 sections, not only to fit the tower in the build envelope, but also to facilitate secondary operations such as depowdering and infiltration. Each build took between 5 and 8 hours to complete. The model was built with zp102 powder. This powder has a fine grain size compared to other powders for this machine. Together with the epoxy-based infiltrant, this gives the strongest products on this device. Depowdering (blowing/sucking away the unused powder) in some areas (see Figure 10b, for example) was very difficult owing to restricted access and intricate detail that broke easily in the uninfiltrated state. Some detail - e.g., the rails - had to be enlarged for this scale model. 


\section{CONCLUSION}

When searching for a 3D printer, a number of important factors should be considered. These were addressed in this paper. However, cost is always the tradeoff.

First, there is material. Considerations may be transparency, strength, or a specific material such as metal or plastic. Drop-on-drop machines normally use stronger materials, and these are sometimes transparent. For metals, either a drop-onpowder device should be considered or, alternatively, a cheaper machine that can produce patterns for secondary casting. Secondary casting is also an option for other materials, such as plastics; however, the lead time of secondary processes can be prohibitive for its use as a concept modeller.

The build envelope determines the size of a component that can be built in one go. Larger components can be built. Careful planning of the assembly process is required. For the best results some experience is needed in deciding where to split the models before printing.

Some printers, especially the drop-on-drop and continuous printing types, require support structures for certain geometries. Other machines use novel techniques to add the support structure as another type of material that can be removed easily afterwards. In some instances the type of geometry that can be built is limited. The drop-on-powder type machines are often advertised as machines that do not require support structures. However, it was found that parts with large and heavy open or overhanging sections still require support structures.

A new user should also find out about post-treatment possibilities of the parts. The drop-on-powder machines often require infiltration to achieve a strong part. This extends the material combinations, but requires the additional time to infiltrate the part.

If the 3D printed parts are to be used as functional prototypes or for fitment testing, then accuracy is important. One should be very careful about the figures quoted by the machine suppliers, as these are often very optimistic, if given at all. Various studies have shown that the accuracy is more often between $0.5-1.0 \mathrm{~mm}$. Table 3 is a useful reference.

Lastly, the case studies have shown that new applications in 3D printing are continuously moving the boundaries. Creative entrepreneurs can find new market niches if the correct combination of machine and supporting technology is applied.

\section{REFERENCES}

[1] Grimm, T. 2003. Rapid prototyping benchmark: 3D printers, T.A. Grimm \& Associates, http:// www.tagrimm.com/ benchmarks/ download_exec_1003.html. 
[2] Wohlers, T.T. 2007. Wohlers Report 2007, State of the industry, annual worldwide progress report, Wohlers Associates Inc, http:// www. wohlersassociates. com/ 2001-Executive-Summary. pdf.

[3] De Beer, D. 2007. SA rapid prototyping landscape, in Wohlers Report 2007, State of the industry, annual worldwide progress report, Wohlers Associates Inc, http:// www. wohlersassociates.com/ 2001-ExecutiveSummary. pdf.

[4] Derby, B. 2003. Ink jet printing of electronic materials, UMIST, Manchester Materials Science Centre.

[5] Levy, G.N. Schindel, R. and Kruth, J.P. 2003. Rapid manufacturing and rapid tooling with layer manufacturing (LM) technologies: State of the art and future perspectives, Annals of the CIRP, 52(2).

[6] RP processes and corresponding technologies. http:/ / www. ennex.com/ fabbers / intro. asp

[7] Chua, C.K. Leong, K.F. and Lim, K.F. 2003. Rapid prototyping: Principles and applications, $2^{\text {nd }}$ edition, World Scientific Publishing.

[8] Diagrammatic representation of RP processes. http:// www.efunda.com/ processes/ rapid_prototyping/ink-jet.cfm (accessed April, 2007).

[9] Sachs, E.M. Haggerty, J.S. Cima, M.J . and Williams, P.A. 1993. US patent 5,204, 055: Three-dimensional printing techniques, April 20.

[10] Dimitrov, D., De Beer, N, 2006 Developing capability profile for the three dimensional printing process, R\&D J ournal of the SAIMechl, 2006, Vol. 22, No. 3, 17-25

[11] Grimm, T. 2005. 3D printer dimensional accuracy benchmark, T.A. Grimm \& Associates, http:// www. dimensionprinting.com/ company/ articles/ tct_toddgrimm. pdf.

[12] 3D System, www.3dsystems.com (April, 2007).

[13] Stratasys, www.stratasys.com (April, 2007).

[14] Dimension, www.dimensionprinting.com (April, 2007).

[15] Z Corporation, www.zcorp.com (April, 2007).

[16] Objet Geometries, www.2object.com (April, 2007).

[17] Solidscape, www. solid-scape.com (April, 2007).

[18] Sanders Design International, www.sandersdesign.com (April, 2007). 
[19] Extrude Hone (ProMEtal), www. extrudehone.com (April, 2007).

[20] Dimitrov, D, Van Wijck, W., De Beer, N, An introduction to rapid casting. Development and investigation of process chains for sand casting of functional prototypes, South African Journal of Industrial Engineering, Vol. 18, No. 1, May 2007. 